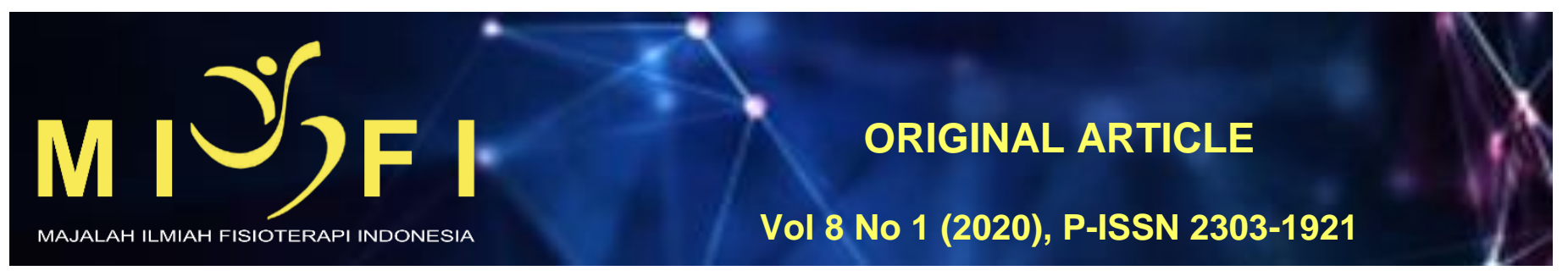

\title{
HUBUNGAN PARTISIPASI LATIHAN HATHA YOGA TERHADAP RENDAHNYA TINGKAT KECEMASAN WANITA PREMENOPAUSE DI LAPANGAN NITI MANDALA RENON
}

\author{
Putu Rina Indahsari', I Made Niko Winaya ${ }^{2}$, I Putu Adiartha Griadhi ${ }^{3}$, Putu Ayu Sita Saraswati ${ }^{4}$ \\ 1 Program Studi Sarjana dan Profesi Fisioterapi Fakultas Kedokteran Universitas Udayana, ${ }^{2}$ Departemen Fisioterapi \\ Fakultas Kedokteran Universitas Udayana, ${ }^{3}$ Departemen Fisiologi, Fakultas Kedokteran Universitas Udayana, ${ }^{4}$ \\ Departemen Fisioterapi Fakultas Kedokteran Universitas Udayana
}

Rina8ndahsari8@gmail.com

\begin{abstract}
ABSTRAK
Penuaan merupakan suatu proses alami yang dialami setiap manusia. Wanita akan memasuki masa klimakterium sebelum masa tua. Klimakterium terbagi menjadi masa premenopause, menopause dan pasca menopause. Premenopause biasanya dimulai pada usia 40-49 tahun yang akan menimbulkan beberapa gejala yang mengakibatkan timbulnya kecemasan bagi wanita. Kecemasan adalah reaksi yang timbul karena adanya suatu masalah yang menekan seseorang. Kecemasan dipengaruhi oleh faktor internal yaitu keadaan fisik dan tipe kepribadian serta faktor eksternal yaitu tingkat pendidikan, dukungan suami, serta status sosial ekonomi. Hatha yoga merupakan aktivitas fisik yang dapat meredakan kecemasan. Tujuan dari penelitian ini adalah mengetahui bagaimana hubungan antara partisipasi latihan hatha yoga dengan tingkat kecemasan wanita premenopause. Jenis penelitian ini yaitu cross sectional analitik dengan teknik consecutive sampling yang dilakukan pada bulan Maret 2019 di Lapangan Niti Mandala Renon Bali. 82 orang wanita usia 40-49 tahun berpartisipasi dalam penelitian ini dan mengisi serangkaian kuisioner seperti kuisioner Hamilton Rating Scale for Anxiety (HRS-A) untuk mengukur tingkat kecemasan, form assessment fisioterapi untuk mengetahui keadaan fisik, kuisioner Eysenck Personality Inventory (EPI) untuk mengukur tipe kepribadian serta kuisioner dukungan suami. Uji analisis menggunakan uji Spearman Correlation. Hasil penelitian terdapat hubungan yang signifikan $p=0,000<p=0,05$ dengan hubungan korelasi kuat serta memiliki nilai yang negatif (Correlation coefficient $-0,687$ ). Kesimpulan dari penelitian ini bahwa, wanita yang mengikuti latihan hatha yoga mengalami tingkat kecemasan yang rendah dibandingkan dengan yang tidak mengikuti latihan hatha yoga.
\end{abstract}

Kata Kunci: hatha yoga, tingkat kecemasan, tipe kepribadian, tingkat pendidikan, tingkat status sosial ekonomi, tingkat dukungan suami, keadaan fisik

\section{THE RELATIONSHIP OF PARTICIPATION IN HATHA YOGA EXERCISE TO THE LOW LEVEL OF ANXIETY IN PREMENOPAUSE WOMEN IN THE NITI MANDALA RENON FIELD}

\begin{abstract}
Aging is a natural process experienced by every human being. Women will enter the climacterical period before old age. The climacteric is divided into premenopausal, menopausal and postmenopausal periods. Premenopause usually starts at the age of 40-49 years which will cause some symptoms that cause anxiety for women. Anxiety is a reaction that arises because of a problem that presses someone. Anxiety is influenced by internal factors, namely the physical condition and personality type and external factors, namely the level of education, husband's support, and socioeconomic status. Hatha yoga is a physical activity that can relieve anxiety. The purpose of this study was to find out how the relationship between participation in hatha yoga exercises and the anxiety level of premenopausal women. This type of research is cross-sectional analytic with consecutive sampling technique conducted in March 2019 at Niti Mandala Renon Bali Field. 82 women aged 40-49 years participated in this study and filled out a series of questionnaires such as the Hamilton Rating Scale for Anxiety (HRS-A) questionnaire to measure anxiety levels, physiotherapy assessment forms to determine physical condition, Eysenck Personality Inventory (EPI) questionnaire to measure personality type and husband support questionnaire. Test analysis using the Spearman Correlation test. The results of the study there is a significant relationship $p=0,000<p=0.05$ with a strong correlation relationship and has a negative value (correlation coefficient $-0,687$ ). The conclusion of this study is that women who take hatha yoga experience low levels of anxiety compared to those who do not take hatha yoga.

Keywords: hatha yoga, anxiety level, personality type, education level, socio-economic status level, husband's support level, physical state
\end{abstract}




\section{PENDAHULUAN}

Penuaan ialah suatu proses alamiah yang akan dilalui oleh semua manusia. Penuaan pada wanita diawali dengan memasuki masa klimakterium yang dimulai pada usia 40-65 tahun. Klimakterium terdiridari masa premenopause, menopause dan pasca menopause. Premenopause merupakan masa paling rentan dikarenakan masa yang paling awal dari peralihan masa reproduksi menuju masa non reproduksi ${ }^{(1)}$. Premenopause biasanya dimulai pada usia 40an tahun dan menimbulkan beberapa gejala seperti, siklus menstruasi yang tidak tetap, hot flashes seperti perasaan panas dari dada hingga wajah, night sweat seperti munculnya keringat dingin pada malam hari, dryness vagina, insomnia, merasa cepat lelah dan depresi. Gejala-gejala tersebut menimbulkan perasaan cemas bagi setiap wanita. Kecemasan itu timbul dikarenakan wanita merasa sudah tidak berharga lagi karena tidak bisa bereproduksi kembali. Kecemasan merupakan suatu reaksi yang timbul dikarenakan seseorang menghadapi suatu masalah ataupun hal baru yang menekan seseorang sehingga dapat mengganggu kegiatan sehari - harinya. Kecemasan dapat dipengaruhi oleh faktor internal maupun eksternal. Faktor internal yaitu kepribadian serta keadaan fisik, sedangkan faktor eksternal yaitu tingkat meliputi tingkat pendidikan, dukungan suami, serta status sosial ekonomi(2).

Kecemasan akan memberikan dampak yang buruk bagi wanita dalam kehidupannya sehari - hari. Dampak buruknya seperti, sering merasa lelah yang berlebihan, otot - otot terasa lemah dan gemetar, seringnya merasa cemas berlebihan dapat memacu organ tubuh yang tidak stabil sehingga mengakibatkan jantung berdebar-debar, timbulnya ketidak harmonisan dalam berumah tangga, menimbulkan depresi serta stressor yang sangat tinggi apabila tidak adanya dukungan keluarga terutama suami, sulit untuk bersosialisasi dilingkungan sekitar dikarenakan individu selalu merasa cemas akan perubahan yang ia alami.

Hatha yoga merupakan salah satu latihan untuk meredakan kecemasan. Hatta Yoga berfokus pada teknik pranayama (olah napas), asana (postur), bandha (kuncian), mudra (gestur), serta relaksasi yang mendalam (Sani 2012). Beberapa teknik gerakan yang sering dilakukan dalam latihan hatha yoga seperti sarvangasana, halasana, utkata pascimottanasana, tuladasana, bhujangasana, yoga mudra, padahastasana, cakrasana. Latihan hatha yoga secara teratur akan memberikan ketenangan pikiran, menyeimbangkan sistem saraf otonom sehingga tubuh menjadi relaks dan dapat mengontrol pengeluaran hormone adrenalin dan epineprin yang berperan dalam peningkatan tekanan darah. Latihan yoga dapat meningkatkan produksi dari hormone endorphin yang merupakan hormone ansietas untuk menurunkan kecemasan(3).

Berdasarkan hal diatas peneliti ingin mengetahui bagaimana hubungan antara latihan hatha yoga dengan tingkat kecemasan wanita premenopause. Adapun sampel yang ditetapkan wanita dengan usia 40-49 tahun. Maka dari itu peneliti ingin memaparkan judul skripsi yaitu "Hubungan Partisipasi Latihan Hatha Yoga terhadap Rendahnya Tingkat Kecemasan Wanita Premenopause di Lapangan Niti Mandala Renon".

\section{METODE}

Dalam penelitian ini menggunakan rancangan penelitian analitik cross sectional yang dilakukan pada bulan Maret 2019 di Lapangan Niti Mandala Renon. Besar Sampel ialah 82 orang wanita dengan rentangan usia $40-49$ tahun. Pengukuran dan penilian pada penelitian ini menggunakan serangkaian kuisioner seperti kuisioner Hamilton Rating Scale for Anxiety (HRS-A) untuk mengukur tingkat kecemasan, form assessment fisioterapi untuk mengetahui keadaan fisik, kuisioner Eysenck Personality Inventory (EPI) untuk mengukur tipe kepribadian serta kuisioner dukungan suami. Uji analisis menggunakan uji Spearman Correlation.

HASIL

Berikut adalah hasil gambaran distribusi frekuensi yang diamati antara lain partisipasi mengikuti hatha yoga, tingkat kecemasan, keadaan fisik, tipe kepribadian, tingkat pendidikan, tingkat dukungan suami dan tingkat status sosial ekonomi sejumlah 82 wanita premenopause di Lapangan Niti Mandala Renon.

Tabel 1. Distribusi frekuensi berdasarkan partisipasi latihan hatha yoga

\begin{tabular}{lcc}
\hline Partisipasi latihan hatha yoga & $\mathbf{F}$ & $\%$ \\
\hline Ya & 42 & $51,2 \%$ \\
Tidak & 40 & $48,8 \%$ \\
\hline Total & 82 & $100 \%$ \\
\hline
\end{tabular}

Tabel 1. Menunjukkan sampel mengikuti hatha yoga 42 orang dan tidak mengikuti sebanyak 40 orang.

Tabel 2. Distribusi Frekuensi berdasarkan tingkat kecemasan

\begin{tabular}{lcc}
\hline \multicolumn{1}{c}{ Tingkat Kecemasan } & $\mathbf{F}$ & $\%$ \\
\hline Tidak ada gejala & 56 & $68.30 \%$ \\
Kecemasan ringan & 18 & $22.00 \%$ \\
Kecemasan sedang & 4 & $4.90 \%$ \\
Kecemasan berat & 4 & $4.90 \%$ \\
Kecemasan sangat berat & 0 & $0 \%$ \\
\hline Total & 82 & $100 \%$ \\
\hline
\end{tabular}

Tabel 2. menunjukkan bahwa responden terbanyak pada tingkatan tidak ada gejala 56 orang responden $(68,3 \%)$, tingkatan kecemasan ringan 18 orang (22\%), tingkatan kecemasan sedang 4 orang $(4,9 \%)$ dan kecemasan berat 4 orang $(4,9 \%)$, sedangkan tingkatan kecemasan sangat berat tidak didapatkan responden. 
Tabel 3. Distribusi Frekuensi Berdasarkan Keadaan Fisik

\begin{tabular}{lcc}
\hline Keadaan Fisik & $\mathbf{F}$ & $\%$ \\
\hline Normal & 82 & $100.00 \%$ \\
Tidak normal & 0 & $0 \%$ \\
\hline Total & 82 & $100 \%$ \\
\hline
\end{tabular}

Tabel 3 menunjukan keseluruhan responden berada pada keadaan fisik normal.

Tabel 4. Distribusi Frekuensi Berdasarkan Tipe Kepribadian

\begin{tabular}{lcl}
\hline Tipe Kepribadian & F & $\%$ \\
\hline Introvert & 37 & $45.10 \%$ \\
Ambivert & 36 & $43.90 \%$ \\
Ekstrovert & 9 & $11.00 \%$ \\
\hline Total & 82 & $100 \%$ \\
\hline
\end{tabular}

Tabel 4 menunjukan bahwa tipe kepribadian yang paling terbanyak ialah pada tipe introvert 37 orang $(45,1 \%)$, tipe kepribadian ambivert 36 orang (43,9\%) dan tipe kepribadian ekstrovert 9 orang $(11 \%)$.

Tabel 5. Distribusi Frekuensi Berdasarkan Tingkat Pendidikan

\begin{tabular}{lcc}
\hline Tingkat pendidikan & $\mathbf{F}$ & $\%$ \\
\hline Rendah & 4 & $4.90 \%$ \\
Menengah & 55 & $67.10 \%$ \\
\hline Tinggi & 23 & $28.00 \%$ \\
\hline Total & 82 & $100 \%$ \\
\hline
\end{tabular}

Tabel 5 menunjukan bahwa responden tingkat pendidikan rendah 4 orang $(4,9 \%)$, tingkat pendidikan menengah 55 orang $(67,1 \%)$ dan pada tingkat pendidikan tinggi 23 orang $(28,0 \%)$.

Tabel 6. Distribusi frekuensi berdasarkan tingkat dukungan suami

\begin{tabular}{lcc}
\hline Tingkat dukungan suami & $\mathbf{F}$ & $\%$ \\
\hline Kurang & 7 & $8.50 \%$ \\
Sedang & 55 & $67.10 \%$ \\
Baik & 20 & $24.40 \%$ \\
\hline Total & 82 & $100 \%$ \\
\hline
\end{tabular}

Tabel 6 menunjukan bahwa tingkat dukungan suami kurang yaitu 7 orang $(8,5 \%)$, tingkat dukungan suami sedang 55 orang $(67,1 \%)$ dan tingkat dukungan suami baik 20 orang $(24,4 \%)$.

Tabel 7. Distribusi frekuensi berdasarkan tingkat status ekonomi

\begin{tabular}{lcc}
\hline Tingkat status ekonomi & $\mathbf{F}$ & $\%$ \\
\hline Rendah & 4 & $4.90 \%$ \\
Sedang & 33 & $40.20 \%$ \\
Tinggi & 26 & $31.70 \%$ \\
Sangat Tinggi & 19 & $23.20 \%$ \\
\hline Total & 82 & $100 \%$ \\
\hline
\end{tabular}

Tabel 7 menunjukan bahwa responden dengan tingkat ekonomi rendah 4 orang $(4,9 \%)$, tingkat ekonomi sedang 33 orang $(40,2 \%)$, tingkat ekonomi tinggi 26 orang $(31,7 \%)$ dan tingkat ekonomi sangat tinggi 19 orang $(23,2 \%)$.

Tabel 8. Distribusi frekuensi berdasarkan usia responden

\begin{tabular}{lll}
\hline Usia Responden & $\mathbf{F}$ & $\%$ \\
\hline 40thn & 16 & $19,5 \%$ \\
41thn & 5 & $6,1 \%$ \\
42thn & 8 & $9,8 \%$ \\
43thn & 3 & $3,6 \%$ \\
44thn & 1 & $1,2 \%$ \\
45thn & 9 & $11 \%$ \\
46thn & 2 & $2,4 \%$ \\
47thn & 7 & $8,5 \%$ \\
48thn & 3 & $3,6 \%$ \\
49thn & 28 & $34,1 \%$ \\
\hline Total & 82 & $100 \%$ \\
\hline
\end{tabular}

Tabel 8 menunjukan bahwa usia responden 49 tahun yang mendominasi sebanyak 28 orang dibandingkan dengan usia lainnya. 
Tabel 9 Hubungan antara partisipasi latihan hatha yoga dengan tingkat kecemasan wanita premenopause

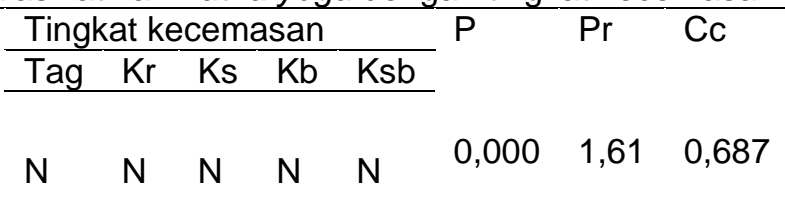

\begin{tabular}{llllll}
\hline \multicolumn{3}{l}{ Hatha } & yoga \\
Ya & 42 & 0 & 0 & 0 & 0 \\
Tidak & 14 & 18 & 4 & 4 & 0 \\
Total & 82 & 18 & 4 & 4 & 0 \\
\hline${ }^{*}$ Keterangan : \\
TAG $=$ Tidak Ada Gejala \\
KR = Kecemasan Ringan \\
KS $=$ Kecemasan Sedang \\
KB = Kecemasan Berat \\
KSB $=$ Kecemasan Sangat Berat \\
PR = Prevalance Ratio
\end{tabular}

Tabel 9 dapat diketahui responden terbanyak pada partisipasi mengikuti hatha yoga 42 orang yang termasuk kedalamtingkatan tidak ada gejala kecemasan. Pada responden yang tidak mengikuti hatha yoga tersebar kedalam semua tingkatan kecemasan seperti (TAG) 14 orang, (KR) 18 orang, (KS) 4 orang dan (KB) 4 orang. Terdapat hubungan yang signifikasn $p=0,000<p=0,005$ dengan hubungan korelasi kuat serta (PR) Prevalence Ratio 1,61.

Tabel 11. Analisa hubungan tingkat kecemasan dengan tingkat pendidikan

*Keterangan :

TAG = Tidak Ada Gejala

$\mathrm{KR}=$ Kecemasan Ringan

$\mathrm{KS}=$ Kecemasan Sedang

$\mathrm{KB}=$ Kecemasan Berat

$\mathrm{KSB}=$ Kecemasan Sangat Berat

$\mathrm{PR}=$ Prevalance Ratio

Tabel 11 menunjukan bahwa responden yang mengikuti yoga dengan tingkat pendidikan rendah tidak ada, tingkat menengah 27 orang, tinggi 15 orang yang tidak terdapat kecemasan sehingga tidak dapat dianalisa. Sedangkan yang tidak mengikuti yoga terdapat tingkat pendidikan rendah 2 orang KR, 2 orang $\mathrm{KB}$, pendidikan menengah 9 orang TAG, 13 orang KR, 4 orang KS, 2 orang KB, pendidikan tinggi 5 orang TAG, 3 orang KR dimana $p=0,007$.

Tabel 12. Analisa hubungan tingkat kecemasan dengan tingkat status sosial ekonomi

\begin{tabular}{|c|c|c|c|c|c|c|c|c|}
\hline \multicolumn{9}{|c|}{ TINGKAT KECEMASAN } \\
\hline & & TAG & $\mathrm{KR}$ & KS & KB & KSB & TTL & $p$ \\
\hline & & $\mathrm{n}$ & $\mathrm{n}$ & $\mathrm{n}$ & $\mathrm{n}$ & $\mathrm{n}$ & & \\
\hline & \multicolumn{7}{|c|}{ Tingkat status sosial ekonomi } & \\
\hline \multirow{6}{*}{ Mengikuti yoga } & Rendah & $0(0 \%)$ & $0(0 \%)$ & $0(0 \%)$ & $0(0 \%)$ & $0(0 \%)$ & $0(0 \%)$ & \\
\hline & Sedang & $11(26,2 \%)$ & $0(0 \%)$ & $0(0 \%)$ & $0(0 \%)$ & $0(0 \%)$ & $11(26,2 \%)$ & \\
\hline & Tingai & $16 / 2810 /$ & & & & $0(0 \circ)$ & $16(381 \%)$ & \\
\hline & IIligyi & & $0(0 \%)$ & $0(0 \%)$ & $0(0 \%)$ & $0(0 \%)$ & $10(30,1 \%)$ & \\
\hline & sangat tinggi & $15(35,7 \%)$ & $0(0 \%)$ & $0(0 \%)$ & $0(0 \%)$ & $0(0 \%)$ & $15(35,7 \%)$ & \\
\hline & Total & $42(100 \%)$ & $0(0 \%)$ & $0(0 \%)$ & $0(0 \%)$ & $0(0 \%)$ & $42(100 \%)$ & \\
\hline \multirow{5}{*}{ Tidak Mengikuti yoga } & Rendah & $1(2,5 \%)$ & $1(2,5 \%)$ & $0(0 \%)$ & $2(5 \%)$ & $0(0 \%)$ & $4(10 \%)$ & \multirow{5}{*}{0,024} \\
\hline & Sedang & $5(12,5 \%)$ & $12(30 \%)$ & $3(7,5 \%)$ & $2(5 \%)$ & $0(0 \%)$ & 22 (55\%) & \\
\hline & Tinggi & $6(15 \%)$ & $4(10 \%)$ & $0(0 \%)$ & $0(0 \%)$ & $0(0 \%)$ & $10(25 \%)$ & \\
\hline & Sangat tinggi & $2(5 \%)$ & $1(2,5 \%)$ & $1(2,5 \%)$ & $0(0 \%)$ & $0(0 \%)$ & $4(10 \%)$ & \\
\hline & Total & $14(35 \%)$ & $18(45 \%)$ & $4(10 \%)$ & $4(10 \%)$ & $0(0 \%)$ & $40(100 \%)$ & \\
\hline
\end{tabular}


*Keterangan :

TAG = Tidak Ada Gejala

$\mathrm{KR}=$ Kecemasan Ringan

$\mathrm{KS}=$ Kecemasan Sedang

$\mathrm{KB}=$ Kecemasan Berat

$\mathrm{KSB}=$ Kecemasan Sangat Berat

$\mathrm{PR}=$ Prevalance Ratio

Tabel 12 responden yang mengikuti yoga pada tingkatan sedang sebanyak 11 orang, tinggi 16 orang, sangat tinggi 15 yang tergolong tidak ada gejala sedangkan yang tidak mengikuti yoga pada tingkatan rendah 1 orang TAG, 1 orang $\mathrm{KR}$, 2 orang $\mathrm{KB}$, tingkatan sedang 5 orang TAG, 12 orang KR, 3 orang $\mathrm{KS}, 2$ orang $\mathrm{KB}$, tingkatan tinggi 6 orang $\mathrm{TAG}, 4$ orang $\mathrm{KR}$, sangat tinggi 2 orang TAG, 1 orang $\mathrm{KR}, 1$ orang $\mathrm{KS}$ dimana $\mathrm{p}=0,024$.

Tabel 13. Analisa hubungan tingkat kecemasan dengan tingkat dukungan suami

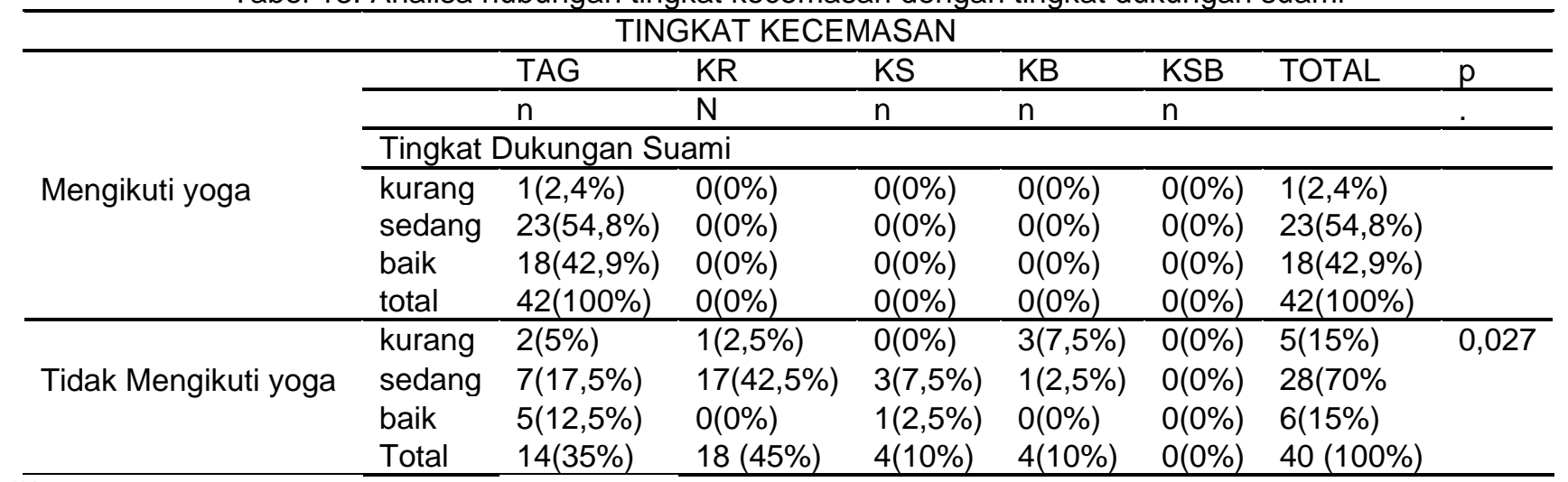

* Keterangan :

TAG = Tidak Ada Gejala

$\mathrm{KR}=$ Kecemasan Ringan

$\mathrm{KS}=$ Kecemasan Sedang

$\mathrm{KB}=$ Kecemasan Berat

$\mathrm{KSB}=$ Kecemasan Sangat Berat

$\mathrm{PR}=$ Prevalance Ratio

Tabel 13 menunjukan bahwa responden yang mengikuti yoga dengan tingkat dukungan suami kurang 1 orang, sedang 23 orang, baik 18 orang yang tidak terdapat kecemasan. Sedangkan yang tidak mengikuti yoga dengan tingkat dukungan suami kurang 2 orang TAG, 1 orang KR, 3 orang KB, tingkat sedang 7 orang TAG, 17 orang KR, 3 orang $\mathrm{KS}$ dan 1 orang $\mathrm{KB}$, tingkat baik 5 orang TAG, 1 orang $\mathrm{KS}$ dengan $p=0,027$.

\section{DISKUSI}

\section{Karakteristik Responden}

Pada penelitian ini didapatkan responden sebanyak 82 orang dimana didapatkan 42 orang $(51,2 \%)$ yang mengikuti yoga dan 40 orang $(48,8 \%)$ yang tidak mengikuti yoga. Dalam tingkatan kecemasan menunjukan bahwa responden terdiri dari 4 tingkatan kecemasan, responden didominasi pada tingkatan kecemasan tidak ada gejala (TAG) yaitu 56 orang $(68,3 \%)$, kemudian diikuti kecemasan ringan (KR) 18 orang (22\%), kecemasan sedang (KS) 4 orang $(4,9 \%)$ dan kecemasan berat 4 orang (4,9\%). Persebaran keadaan fisik responden menunjukan seluruh responden dengan keadaan fisik yang normal. Tipe kepribadian pada penelitian ini didominasi pada tipe introvert yaitu sebanyak 37 orang $(45,1 \%)$ dibandingkan tipe ambivert 36 orang (43,9\%) dan tipe ekstrovert 9 orang (11\%). Tingkat pendidikan yang mendominasi ialah pada tingkat pendidikan menengah yaitu 55 orang $(67,1 \%)$ dibandingkan tingkat pendidikan rendah 4 orang $(4,9 \%)$ dan tingkat pendidikan tinggi 23 orang $(28 \%)$. Tingkat dukungan suami terlihat dukungan suami sedang yang mendominasi yaitu 55 orang $(67,1 \%)$ dibandingkan dukungan suami kurang 7 orang $(8,5 \%)$ dan dukungan suami baik 20 orang (24,4\%). Tingkat status sosial ekonomi yang mendominasi yaitu tingkatan sedang 33 orang (40,2\%) dibandingkan tingkat ekonomi rendah 4 orang (4,9\%), tingkat ekonomi tinggi 26 orang (31.7\%) dan tingkat ekonomi sangat tinggi 19 orang (23,2\%). Persebaran usia responden menunjukkan bahwa responden usia 49 tahun merupakan responden yang paling banyak dibandingkan dengan usia lainnya yaitu 28 orang (34.1\%).

\section{Hubungan antara Partisipasi Latihan Hatha Yoga dengan Tingkat Kecemasan Wanita Premenopause}

Hubungan antara partisipasi latihan hatha yoga dengan tingkat kecemasan wanita premenopause di Lapangan Niti Mandala Renon diperoleh signifikan dimana $\mathrm{p}=0,000$ dimana $\mathrm{p}<0,05$. Tabel 9 terdapat (PR) Prevalence Ratio sebesar 1,61 yang berarti setiap responden yang mengikuti partisipasi latihan hatha yoga mengalami penurunan tingkat kecemasan sebesar 1,61. Correlation coefficient -0,687 sehingga hubungan ini memiliki korelasi yang kuat. Sejalan dengan hasil penelitian oleh Saputra pada tahun 2016 dimana terdapat hubungan yang signifikan antara latihan yoga dengan tingkat kecemasan ${ }^{(4)}$. Dalam penelitiannya juga menyebutkan siklus menstruasi yang tidak teratur pada masa premenopause sering menimbulkan rasa cemas dan ini merupakan aspek pemicu timbulya tingkat kecemasan yang tinggi bagi wanita. Pada penelitian Setyaningsih (2018) juga menyebutkan bahwa setelah diterapkan latihan yoga semua peserta pada penelitiannya mengalami penurunan tingkat kecemasan dan dengan melakukan yoga merupakan cara penghilang kecemasan yang baik(5). Selain itu pada penelitian Yulinda dkk (2017) Latihan hatha yoga secara teratur akan memberikan ketenangan pikiran, menyeimbangkan sistem saraf otonom sehingga tubuh menjadi relaks 
dan dapat mengontrol pengeluaran hormone adrenalin dan epineprin yang berperan dalam peningkatan tekanan darah . Latihan yoga dapat meningkatkan produksi dari hormone endorphin yang merupakan hormone ansietas untuk menurunkan kecemasan ${ }^{(3)}$.

\section{Hubungan tingkat kecemasan terhadap tipe kepribadian, tingkat pendidikan, tingkat status sosial ekonomi dan tingkat dukungan suami}

Tabel 5.10 tingkat kecemasan dengan tipe kepribadian yang mengikuti yoga tida terdapat hubungan sedangkan yang tidak mengikuti yoga terdapat hubungan namun tidak signifikan $p=0,976>p=0,05$. Sejalan dengan penelitian dari Sholihah pada tahun 2016 menyebutkan bahwa tidak ada hubungan yang signifikan antara tipe kepribadian ekstrovert maupun introvert terhadap tingkat kecemasan(6). Tabel 11 tidak terdapat hubungan antara tingkat kecemasan dan tingkat pendidikan yang mengikuti yoga. Sedangkan yang tidak mengikuti yoga terdapat hubungan yang signifikan $p=0,007<p=0,005$. Hal serupa juga dapat dibuktikan dalam jurnal penelitian Sholichah dan Anjarwati pada tahun 2014, dimana berdasarkan hasil penelitiannya menunjukkan bahwa ada hubungan antara tingkat pendidikan dengan tingkat kecemasan pada wanita usia 40-50 tahun dalam menghadapi menopause ${ }^{(7)}$. Tabel 11 kecemasan responden yang mengikuti hatha yoga tidak terdapat pengaruh dengan tingkat pendidikan, sedangkan tingkat kecemasan responden yang tidak mengikuti hatha yoga tersebar dalam setiap tingkatan kecemasan dan dipengaruhi oleh faktor pendidikan dari responden itu sendiri. Tabel 12 dapat kita lihat bahwa hasil penelitian tidak dapat dianalisa. Sedangkan dalam hubungan tingkat kecemasan dengan tingkat status sosial ekonomi responden yang tidak mengikuti partisipasi latihan hatha yoga memiliki hubungan yang signifikan dimana $p=0,024<p=0,05$. Terbukti dalam penelitian Wigati dan Kulsum pada tahun 2017, menyebutkan bahwa tingkat ekonomi memiliki hubungan yang signifikan terhadap tingkat kecemasan wanita premenopause ${ }^{(8)}$. Tabel 12 tingkat kecemasan pada responden yang mengikuti partisipasi latihan hatha yoga berada pada tingkatan terendah atau tidak ada gejala serta tidak terdapat faktor pengaruh dari tingkat status sosial ekonomi, berbanding terbalik dengan tingkat kecemasan pada responden yang tidak mengikuti partisipasi latihan hatha yoga yang tingkat kecemasannya semakin meninggi serta tersebar kedalam beberapa tingkatan kecemasan dan terdapat pengaruh dari tingkat status sosial ekonomi dari responden.Tabel 13 tingkat kecemasan pada responden yang mengikuti partisipasi latihan hatha yoga dengan tingkat dukungan suami tidak dapat dianalisa. Sedangkan hubungan tingkat kecemasan responden yang tidak mengikuti partisipasi latihan hatha yoga dengan tingkat dukungan suami terdapat hubungan yang signifikan dimana $p=0,027<p=0,05$. Menurut hasil penelitian oleh Putri dkk pada tahun 2017 menyebutkan bahwa terdapat hubungan yang signifikan antara timgkat dukungan suami terhadap tingkat kecemasan wanita premenopause ${ }^{(9)}$. Maka dapat disimpulkan bahwa hubungan tingkat kecemasan pada responden yang mengikuti partisipasi latihan hatha yoga berada pada tingkatan rendah serta tidak terdapat faktor pengaruh dari tingkat dukungan suami respondennya, sedangkan pada tingkat kecemasan responden yang tidak mengikuti partisipasi latihan hatha yoga terdapat tingkat kecemasan yang semakin meninggi serta terdapat pengaruh dari tingkat dukungan suami. Dalam penelitian ini didapatkan hasil dengan mengikuti partisipasi latihan hatha yoga kecemasan seseorang akan semakin membaik, begitupula sebaliknya bagi responden yang tidak mengikuti partisipasi latihan hatha yoga ini terdapat tingkat kecemasan yang semakin memburuk serta terdapat pengaruh dari faktor - faktor pengaruh kecemasan lainnya.

\section{SIMPULAN}

Dilihat dari hasil penelitian diatas maka dapat disimpulkan bahwa, wanita premenopause yang mengikuti latihan hatha yoga mengalami tingkat kecemasan yang rendah dibandingkan dengan yang tidak mengikuti latihan hatha yoga.

\section{DAFTAR PUSTAKA}

1. Fruitasari, m. Kus fitriani. 2017. Dampak senam aerobik low impact terhadap tingkat kebugaran wanita premenopause. Volume 5, nomor 1, juni 2017. Fakultas Ilmu Kesehatan Unika Musi Charitas Palembang.

2. Christian, Jan. 2017. Hubungan antara tingkat kecemasan dan Prestasi akademik pada siswa sekolah Menengah atas di Denpasar. Skripsi. Fakultas Kedokteran Universitas Udayana.

3. Yulinda, Purwaningsih Dewi \& Sudarta, Cherly Marliana. 2017. Latihan Yoga Dapat Menurunkan Tingkat Kecemasan pada Siklus Mentruasi Remaja Puteri. Jurnal Ners dan Kebidanan Indonesia. Vol 5 no 1 Tahun 2017 20-26

4. Saputra, Dhymaz Rangga Bistara. 2016. Pengaruh Senam Yoga Terhadap Tingkat Kecemasan Wanita Pra Menopause (Studi Pada Lychel Gym Aerobik dan Yoga 35-45 tahun Surabaya). Jurnal Kesehatan Olahraga Vol.06 No.2 Edisi Oktober 2016 hal $222-229$

5. Setyangingsih, Devi. 2018. Penerapan yoga dengan music klasik terhadap tingkat kecemasan wanita premenopause di bpm h. Lusi sumartini s, st. Kecamatan pejagoan kabupaten kebumen.

6. Sholihah j. 2016. Hubungan tipe kepribadian ekstrovert dan introvert dengan tingkat kecemasan remaja yang mengalami dismenorea di smpn 11 jember. Universitas Jember.

7. Sholichah,Nur \& Anjarwati, Restu. 2014. Hubungan tingkat pendidikan dengan tingkat kecemasan wanita usia $40-$ 50 tahun dalam menghadapi menopause.

8. Wigati, Atun dan Kulsum, Ummi. 2017. Kecemasan wanita pada masa menopause berdasarkan tingkat ekonomi. home $>$ vol 1, no 2 (2017)

9. Putri, Valentina Tanjung. 2013. Pengaruh Latihan Hatha Yoga Terhadap Tingkat Kecemasan. Skripsi. Program studi fisioterapi fakultas kedokteran universitas hasanuddin makassar. 